\title{
A HISTORICAL LOOK AT ARCHITECTURE IN IOWA
}

The following Architectural Studies were selected from a large number of similar studies done by under-graduate students at Iowa State University, Ames, Iowa. According to Iowa State Professor Lawton Patten, the papers were the byproduct of the study of the History of Architecture and their main value, at the time, was to stimulate the students' interest in making them aware of the many interesting buildings scattered throughout the state of Iowa.

The Department of Architecture at Iowa State University has given these reports to the Iowa Historical Library, Des Moines, in memory of the late Leonard Wolf of Ames, Head of the Department of Architecture from 19.53 to 1962. The complete Leonard Wolf Collection is now filed in the Historical Library for availability to the public.

It should be noted that the students who did these studies were not historians but under-graduate students interested in the study of architecture. However, because of the interest of these studies and the fine photographs of the old buildings of Iowa, we feel that they are of significance to be here published. It is hoped that these studies will awaken a public interest in the preservation of Iowa's historical structures and that further action will be taken in the research, recording and preservation of Iowa's old buildings.-the Editor.

\section{THE FIRST LOG CABIN IN HARDIN COUNTY, IOWA}

\section{Study by Alan C. Balhorn}

The first settlers in Hardin County, Iowa, came from 1llinois in 1849. After fording the Iowa River near Eldora, Iowa, they traveled west another three miles to a good timber stand and began their community. Eleven cabins were built within sight of each other and the crops of flax and corn were planted. The town of Eldora was founded in 1853 and the growth of this community of eleven cabins ended. 


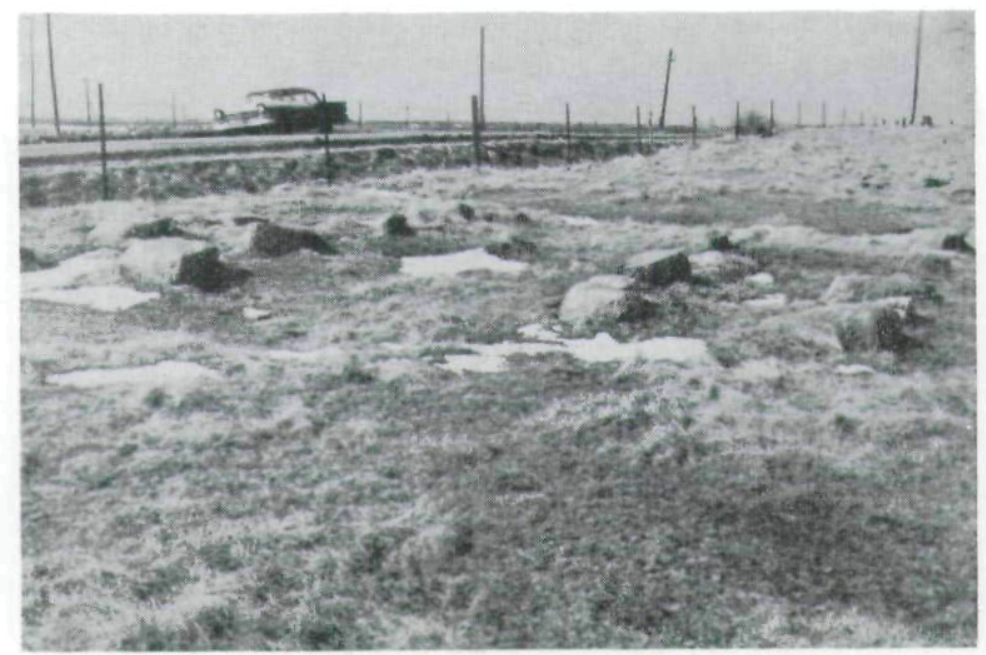

Original Location of Cabin

Note Four Rows of Stones

The first settler of this community was Thomas Houser. $\mathrm{He}$ and the other settlers built their cabins from local materials without any of the conveniences of today. The cabins were made of logs notched over each other at the corners and held together with wooden pegs. Clay and fist-sized stones were used to fill the cracks between the logs and several rows of large stones served as the foundation. A fireplace was used to heat the cabins and to cook the pioneers' meals. The window openings were covered with oiled paper and the plank doors had leather or pounded-iron hinges. The cabins of the wealthier pioneers had rag quilts on the walls and on the floor.

The only remaining cabin of the eleven was the first cabin to be built. It was built by C. C. Shephard between 1849 and 1854. The official location of the cabin is the N.W. corner, S.E. quarter, section 18-87-20, Hardin County. In laymen's terms, this would be two and one-quarter miles west and one mile south of the Hardin County Court House in Eldora, Iowa.

The original location of the cabin is believed to be south 
of the present location. The original foundation at that location was four rows of large stones which are shown in the accompanied photograph. The land around the cabin is believed to be unturned prairie sod.

The earliest record of the cabin listed in the Hardin County Auditor's records is March 19, 1855; the title was in C. C. Shephard's name. Other title holders listed in the Auditor's records are Joseph Crawford, John Lytle, C. Burling, Sarah Lytle, Sweet and wife, Carl and Marie Schwebke, Wilhelm and Caroline Marske, Verner Dobbrunz, and Fred Dobbrunz. The present owner of the cabin, Fred Dobbrunz, is interested in restoring the cabin as a historical landmark.

The cabin has not been lived in for the last 65 years and has since been used as a corn crib and grain bin. As can be seen by the photographs, the cabin is in a terrible state of disrepair. The clay and stone infilling has almost entirely fallen away and many of the logs have rotted away; the floors are in a heaved condition, the ceilings are sagging and the foundation is in a crumbling condition.

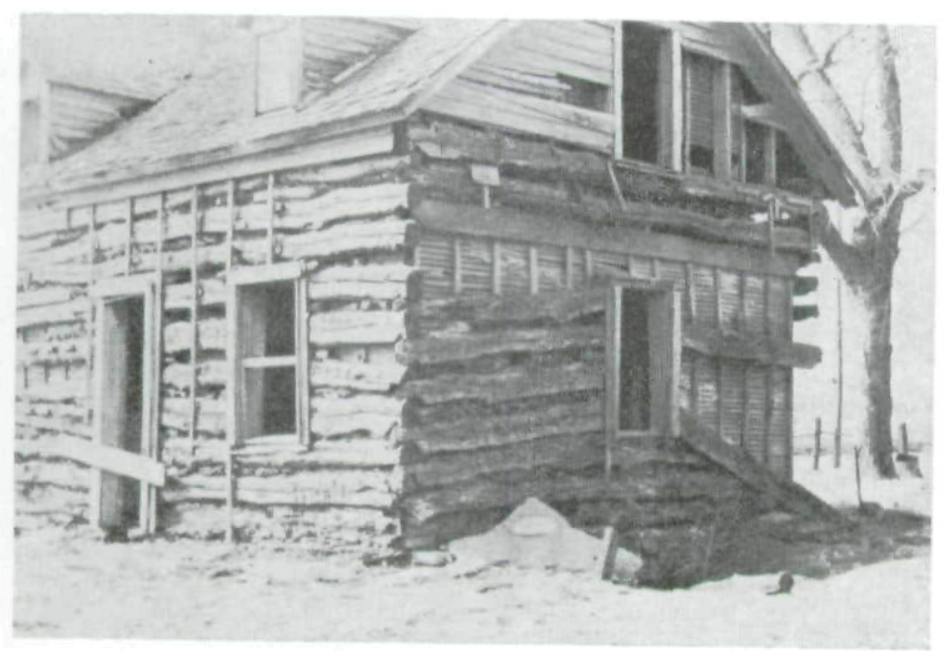

Southeast Corner of Cabin 


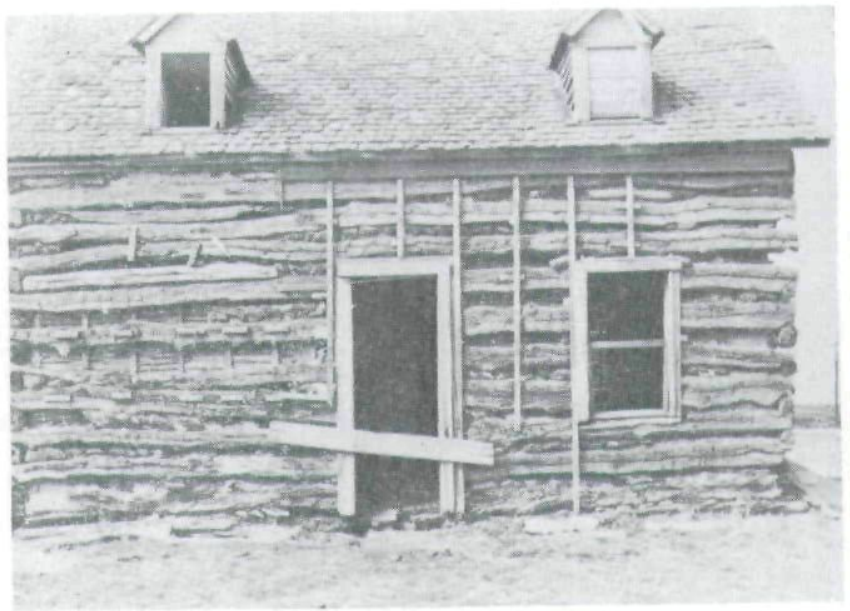

South Elevation of Cabin
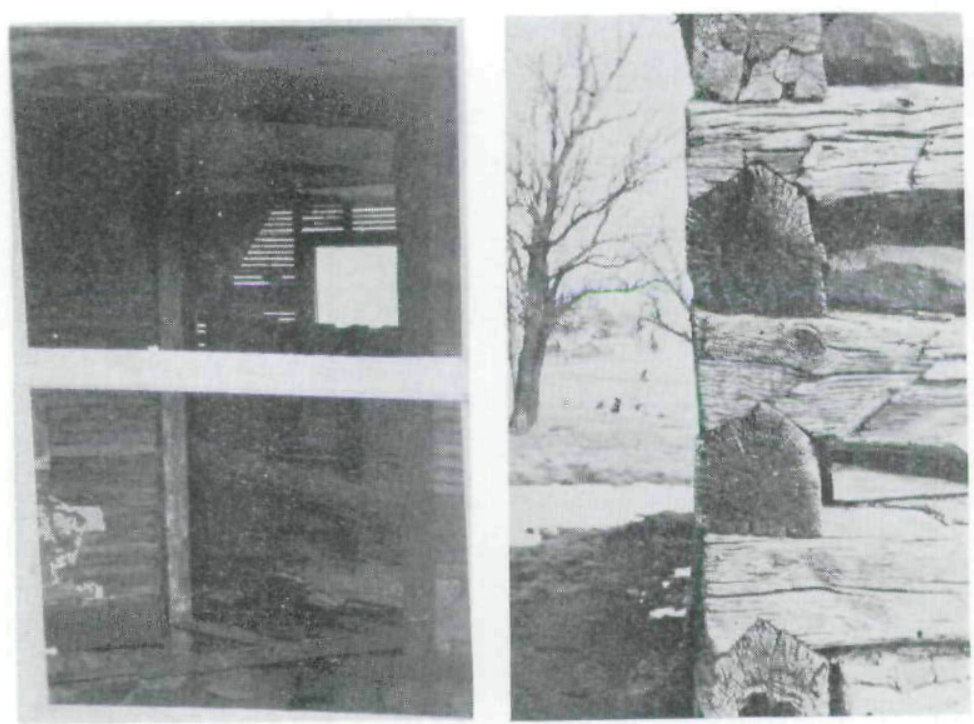

Left-Photo Taken Through Window of West Elevation.

Right-Northeast Corner of Cabin. Nore How the Logs Are Notched Over One Another. 


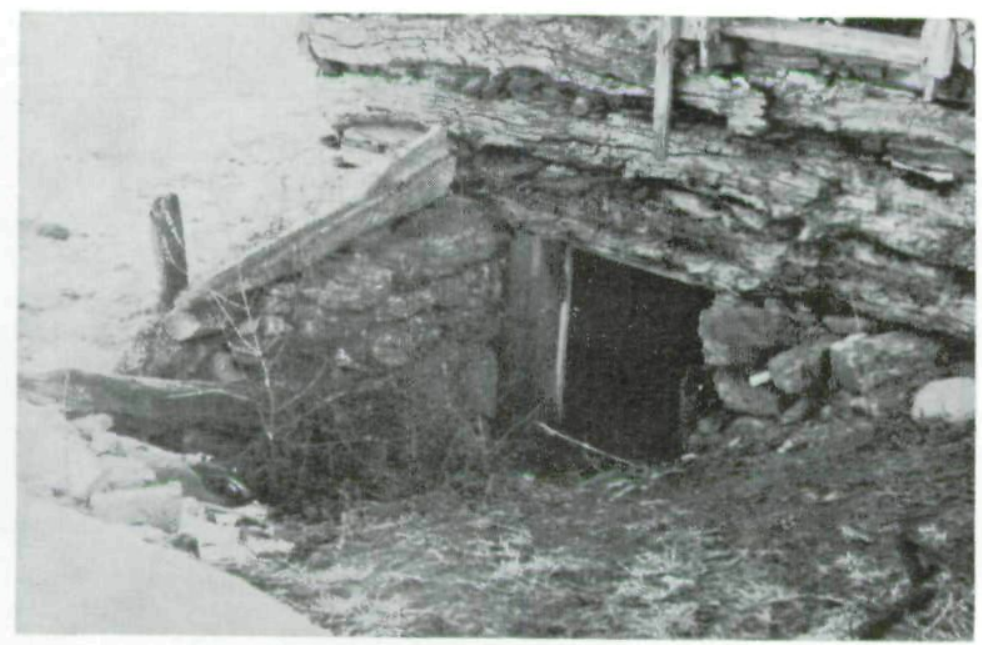

Basement Entrance to Cabin

Editor's note-It was hoped at the time of this study that this cabin would be restored as a historical landmark. However, no action was taken and this first cabin of Hardin County has since been destroyed because of the hazards of the crumbling foundation.

THE DUMOND HOUSE AT BELMOND, IOWA

Study by Howard Pals

The Dumond House stands on a hillside overlooking the larger portion of the town of Belmond, Iowa. From a distance, the house appears to be nothing special. A closer inspection and investigation reveals the interesting life the house has led.

The Dumond House was built in 1856, the year that Belmond was founded. The house is named after one of the co-founders of the town, Archie Dumond. Dumond built the house with bricks made from the red clay found near the Iowa River, which runs through the town. Black walnut was used in the construction for beams and lintels over doors and windows. Both the brick and wood are still in excellent condition 


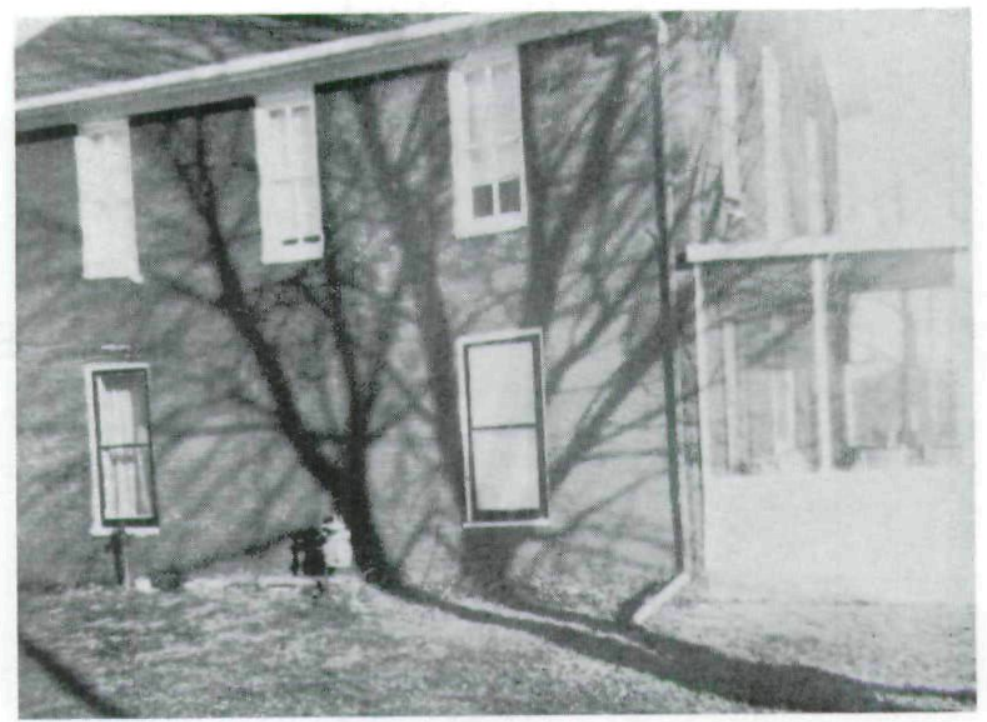

Dumond House

considering the age of the house.

The house was originally built to be a private residence. The Dumond family lived in the house only a few years, they then rented it out. In 1866, rent on the house for a month was only $\$ 1.50$. The house was later used as a community stronghold to house 32 women and children during the construction of a fort. The settlers of Belmond lived in constant fear of an Indian attack and would not leave the women and children alone at home even during the time when they were occupied with the building of the fort.

In the late 1800 's, the Dumond House was used as a stagecoach station. An addition was built on the north side of the existing structure to be used as a kitchen and a bar. This addition was built with native lumber though and not with bricks.

For the past 60 to 70 years, the house has been in use as a residence. Modern plumbing and other improvements were added from time to time as they were needed.

Editor's note-The above study was done in 1964; at that time the town of Belmond was considering buying the house 
for use as a town museum. However, Dumond House was destroyed by the fall tornado of 1966 before any purchasing action was taken. Stewart Eckhoff was the last owner of the house.

BLUE PLACE IN EAgLE GROVE, IOWA

Study by Duane L. Miller

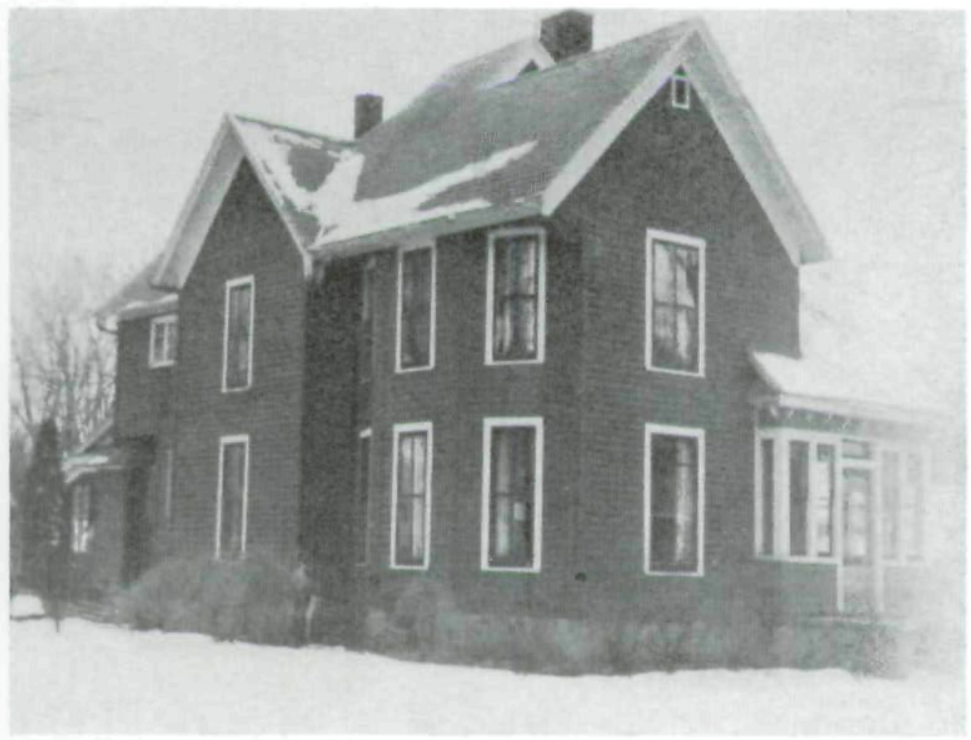

Blue Place

Blue Place, presently owned by Robert Blue, past governor of Iowa, was built in 1894 by Marcus Olsen, a capable carpenter of good standing in Eagle Grove. Mr. Olsen designed and built at least 15 houses in Eagle Grove, but whether he was the exclusive designer of this home is rather doubtful.

This house was built for Mr. and Mrs. R. M. Smallpage, a druggist and banker in Eagle Grove. Mrs. Smallpage was born and educated in Boston and when she arrived in Iowa, she wasn't pleased by the homes and the buildings of the late 19th century in Eagle Grove. Therefore, during the designing process of the house, she entered into the discussions 
in such a manner that Mr. Olsen built an entirely different house. The Blue Place was thus considered a model for other houses in the Eagle Grove area.

The house was built as a farm country house on a corner. Except for removal of the pipe fence that used to surround the house, there have been no changes in the exterior of the house. The house is still painted a dull red color, which is typical of the area in which Mrs. Smallpage grew up.

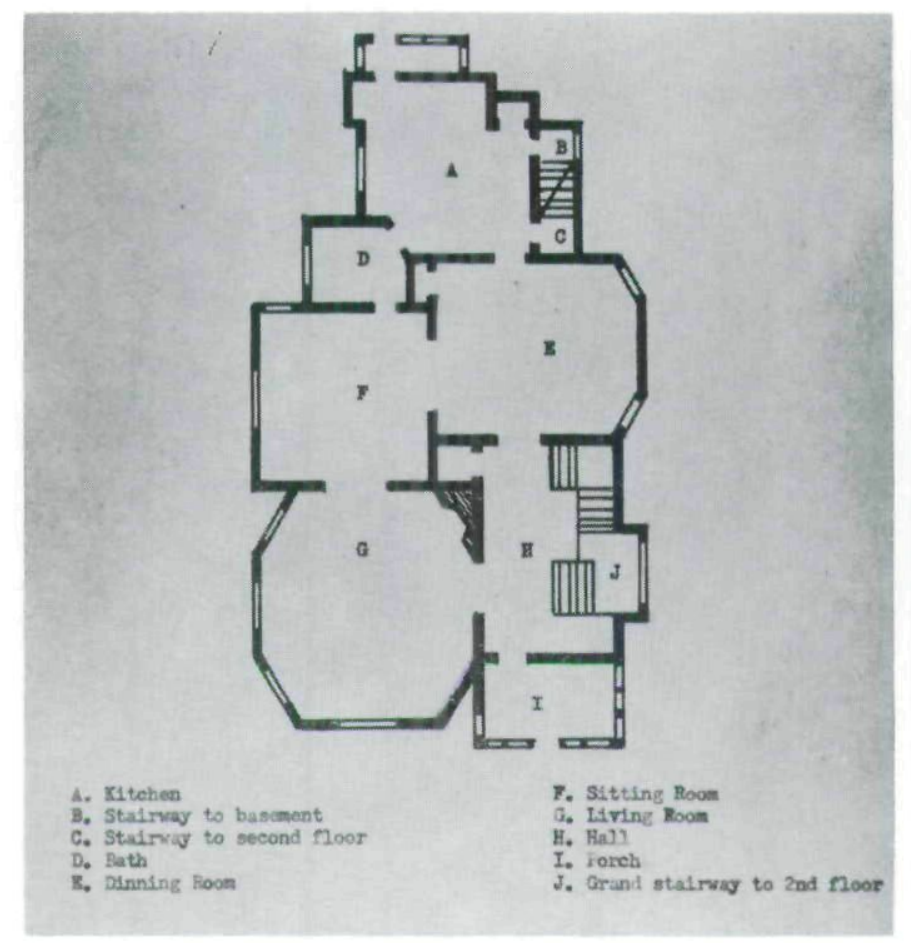

First Floor Plan

The house was carefully planned and the only major alterations on the interior are in the kitchen, which now looks like a room from another house. The Blue's altered the kitchen in only removing two south windows, but the room shows signs of previous alterations. The only possible way to tell what other alterations have been made would be to look into 
the framing of this area. However, even though the kitchen has been altered at different times, it still works with the house.

An alteration in the dining room in 1949 removed a socalled gothic rose window from the west side.

The grand stairway is remarkable as it was a ticklish proportional problem for the carpenters, but the problem was solved very well. The interior trim was hand planed, but after many sandings in recent years, seems to have been milled.

The materials used in the house were locally purchased.

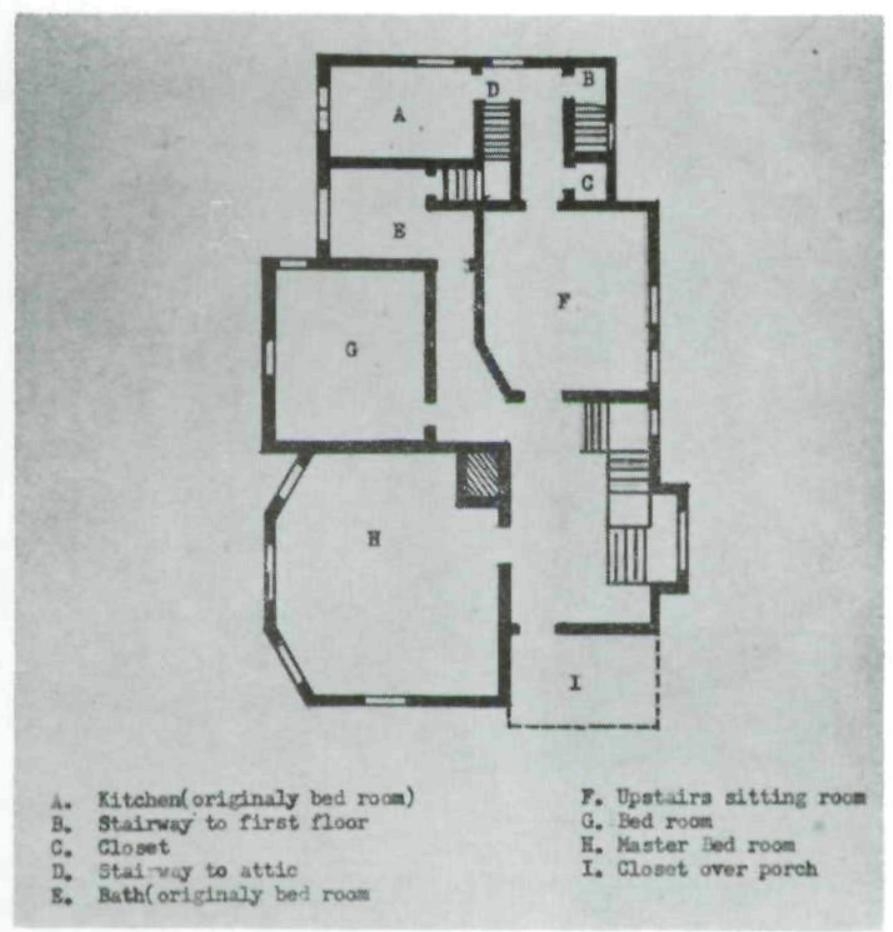

Second Floor Plan 


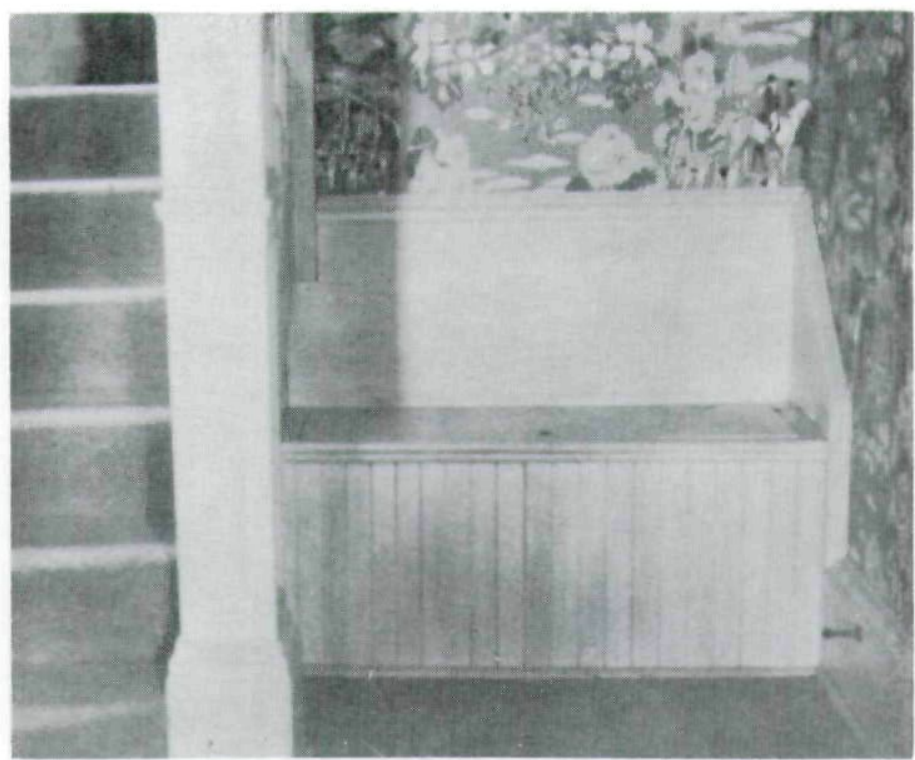

Box Chair by Staircase

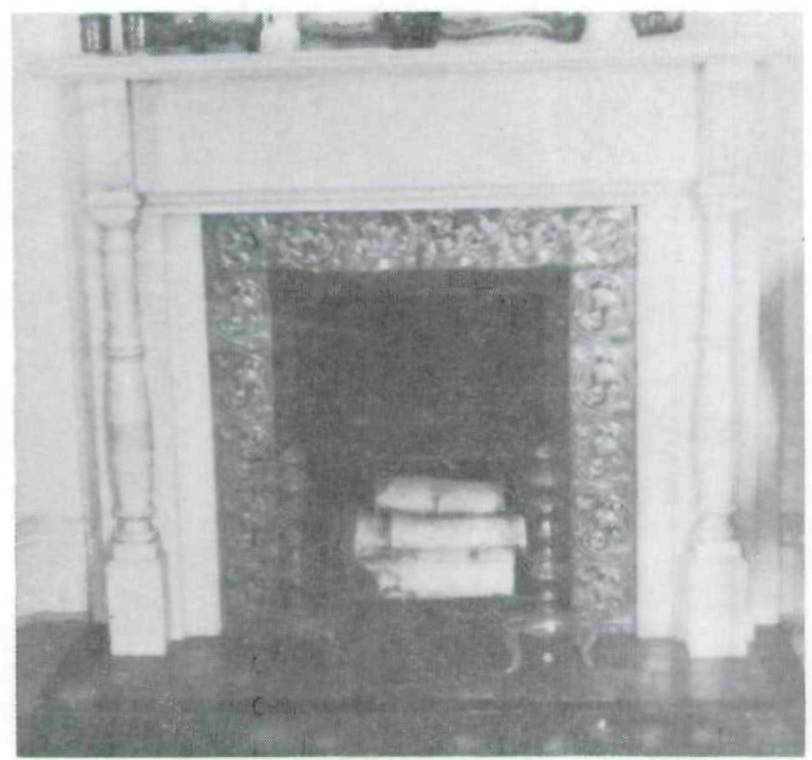

Fireplace 


\section{ARMBRUSTER PLACE OF EAGLE GROVE, IOWA}

\section{Study by Duane L. Miller}

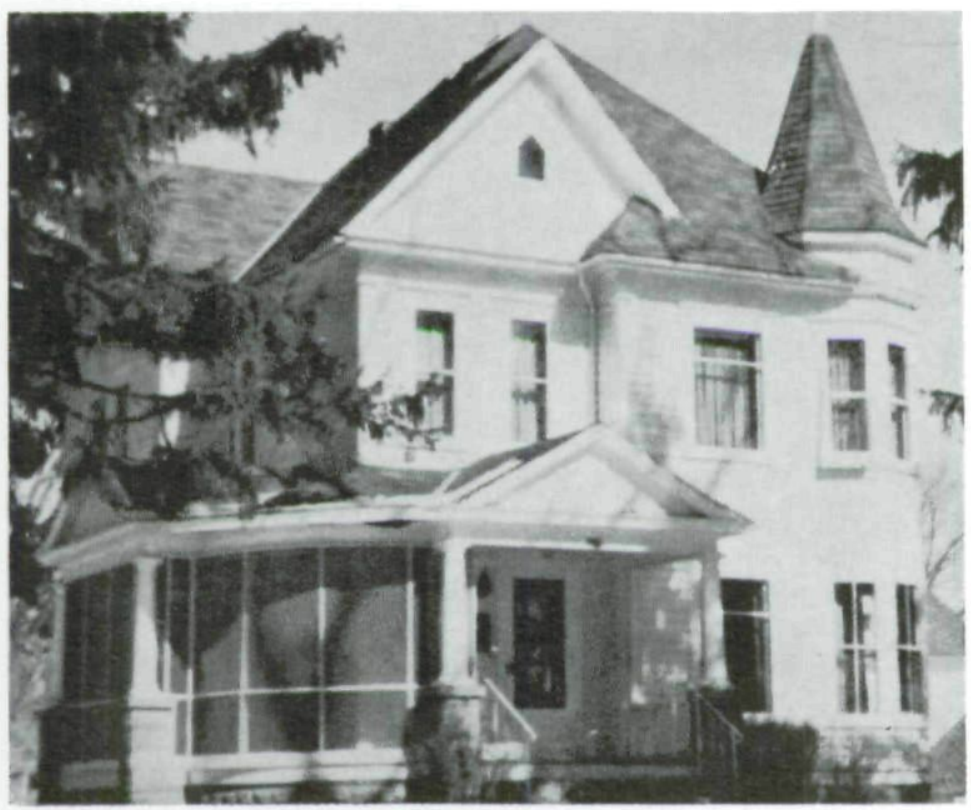

Armbruster Place

Armbruster Place was named after the Armbruster family who lived in this house from 1899 to about 1950. The house was designed by David Paine in 1896 with the help of John Middleton, who was then considered the finest carpenter in Wright County. Raymond Paine, a son of David Paine, presently lives near Eagle Grove; he told of the house plan being carefully drawn on a pine board and showing where every member of the Paine family, the house's first residents, was to be placed. Mr. Paine can remember his father and Mr. Middleton working all winter on the smallest details of the plan.

John Middleton cut the rafters on the ground, reading the dimensions from the house plan. Not only was he a good man on structure and framing, but also, he was able to plane the butternut lumber into very fine moldings and interior trim work. It is said he had over 150 block planes. 
David Paine was the contractor of these buildings. With the help of John Middleton, he was able to put his ideas on the pine board and see them built. He could have built these houses by himself but he didn't have the feeling for ornamentation which Middleton had. So together the team of Middleton and Paine not only designed and built this home but at least 20 other homes in the area. However, Armbruster Place is considered their finest.

The Paine family lived in the house for two years at which time David Paine retired to the country where he continued to build to satisfy his ideas for good home construction and design. The house was rented for a year until the Armbruster family bought it. Mr. Armbruster was the owner-operator of a large hardware store in Eagle Grove and a prominent man in the town.

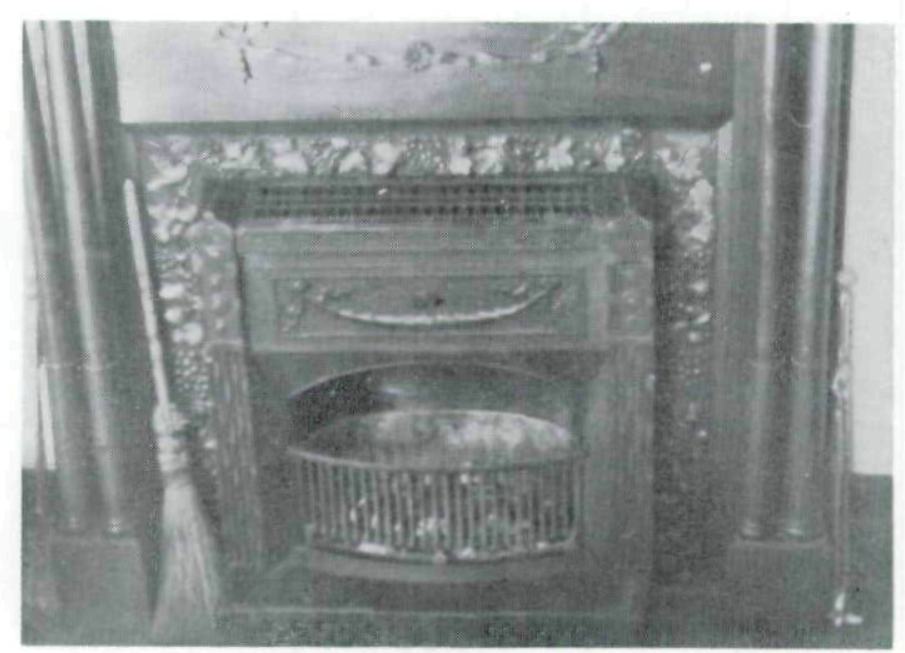

Fireplace

Armbruster Place stood unmodified until the early part of the 1950's. Since then the house has been repainted inside and out and the kitchen modified in the newest trends. The family who altered the kitchen were careful to save the splendid tin ceiling which today, even though painted white, shows the clear masterful art of the local tinsmith. 


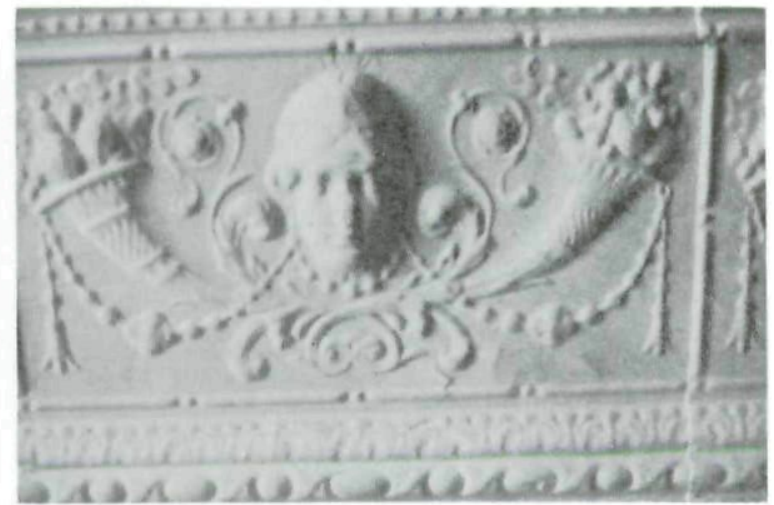

Kitchen Ceiling Detail

The house was built completely from native materials. The lumber came from the local sawmill, the stone for the foundation from a nearby quarry and the beautiful butternut trim throughout the inside of the house, from Mr. Paine's farm.

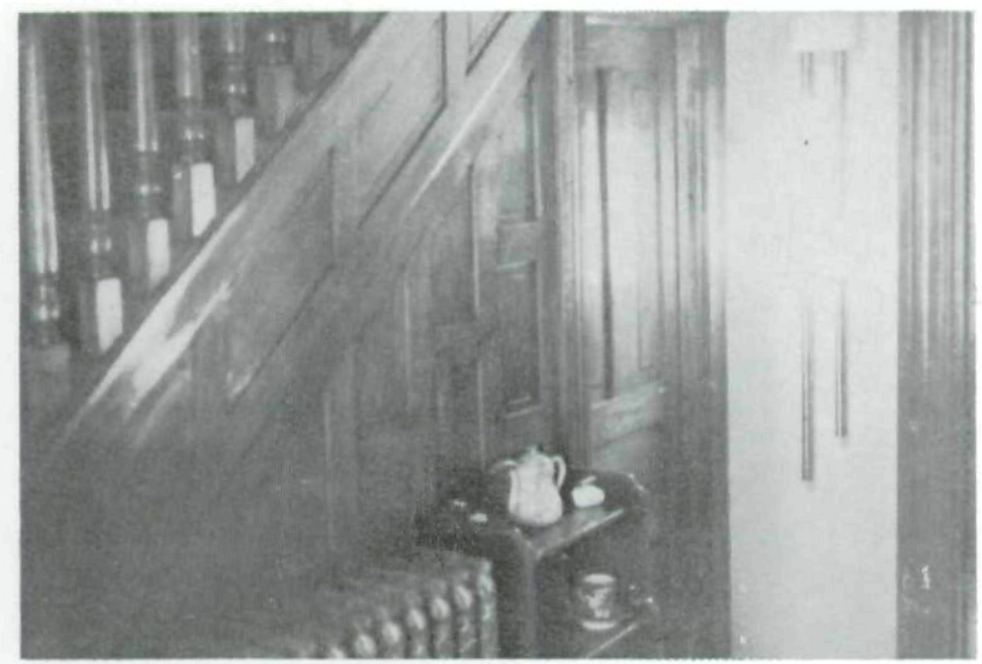

Stairway Panneling 
The front porch and the classic cornice covering the corner pilasters are examples of Greek Revival in architecture. However, the style of the house is really Mr. Paine's own imagination of what he thought a good planned house should be. The house is spacy, warm and comfortable.

The only true structural modification in the house is the back stairway which was removed to make room for a wash room and closets. The present owners of Armbruster Place are the Myers, who plan to keep the house as it is except for enlarging the fireplace.

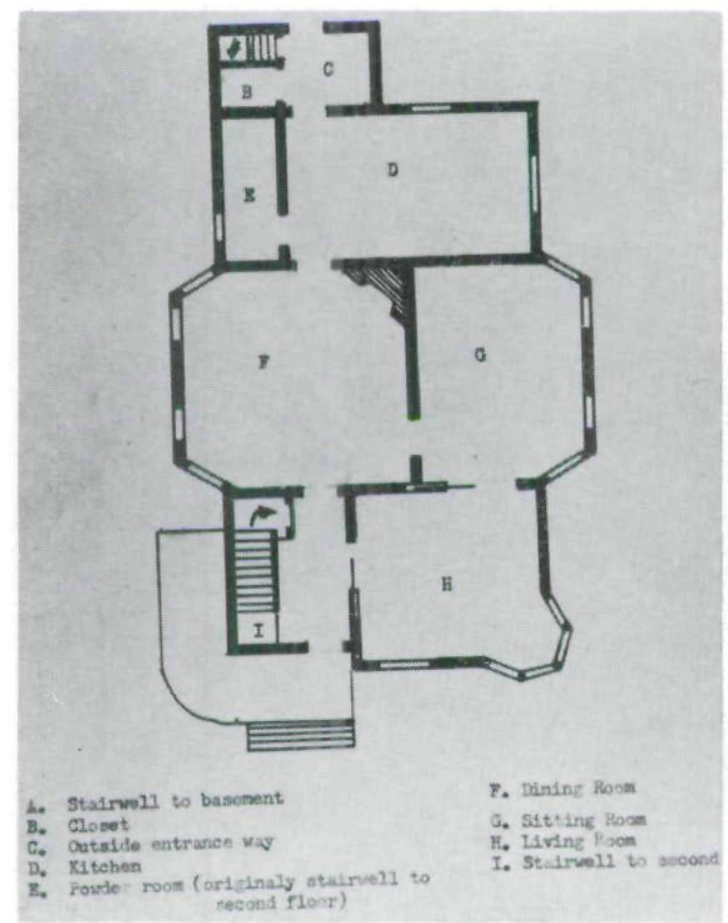

First Floor Plan 


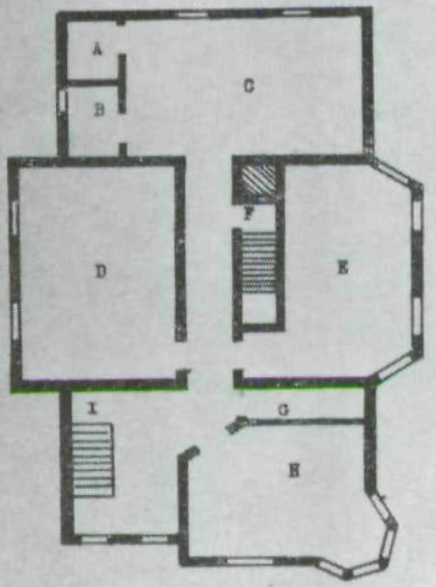
A. Closet (arledinaly atalivall to first floor)
7. St.atre11 to attie
A. Cioset (arkinaly stalivali to first noor
Q. Clasot
C. DeI roon
B. Dint is sitein room
I. Stainoli from first f?
z. De: Roca

Second Floor Plan

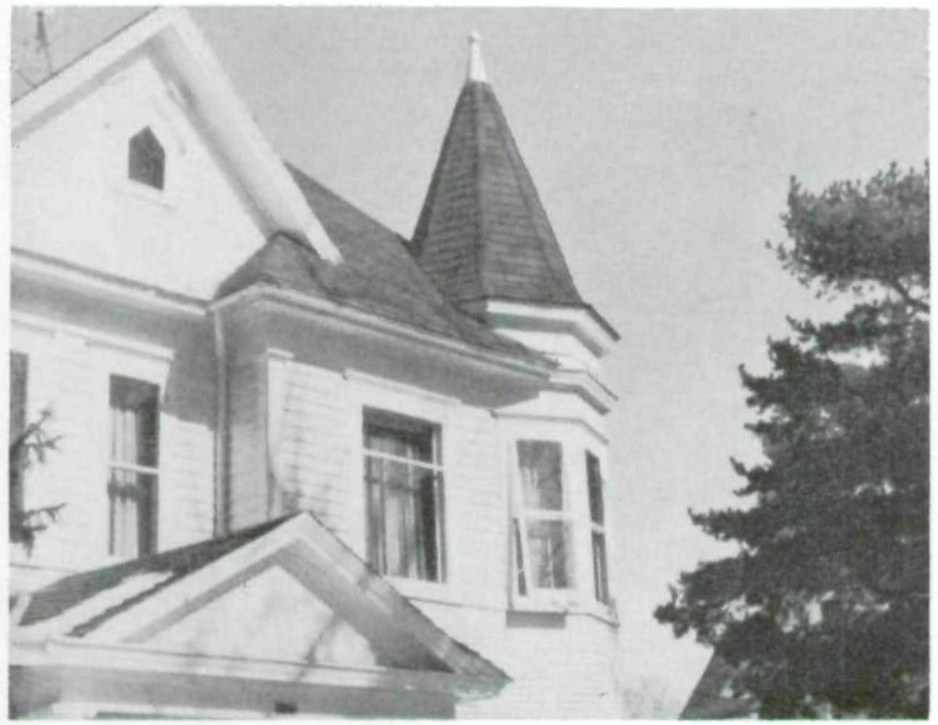

Gable Over Porch on South Side 
TARA STAGECOACH HOUSE

\section{Study by Ann Louise Lind}

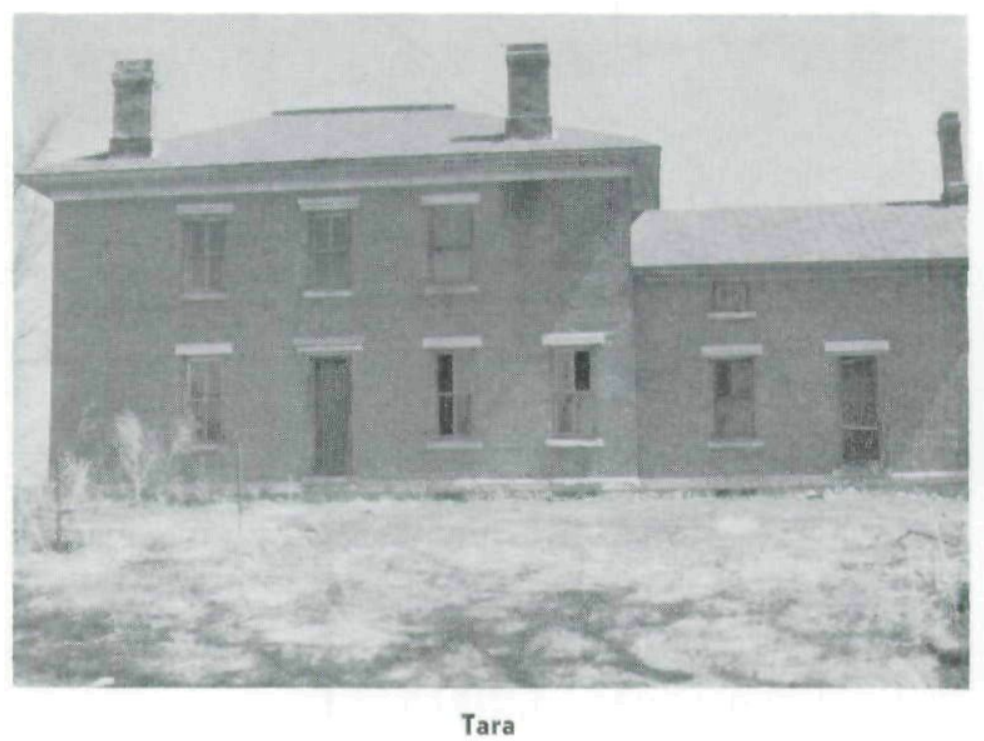

Seven miles west of Fort Dodge, Iowa, a quarter of a mile from a new blacktop road, sits in serene silence an old landmark known as the Tara Stagecoach House. The house is familiar to many residents of Webster County. It was built by Stephen Powers, one of the area's early settlers.

Stephen Powers brought his family from Bangor, Maine, in 1856. The story is that he had gone to California in search of gold a few years before by way of the sea route around Cape Horn, the southern tip of South America. He returned to Maine overland, passed through Iowa and decided to bring his family here.

When he first brought his family to Iowa, Stephen Powers built a log cabin just south of the site where he built an 11-room mansion two years later in 1858. The new house was built in the common architectural style of New Englandhigh ceilings, narrow windows, and a "summer" kitchen jutting out to the rear. 
Stephen and Mary Powers built the house with their own brick made in a kiln nearby. Clay was taken from along Lizard Creek, which runs through the original 530-acre tract. Walnut and oak from trees on the farm were used extensively for structural members and woodwork. The rough wood was shipped by stage to Boone where it was finished and shipped back to Tara. It took two years to build the house.

The house has six rooms upstairs, one of which runs the entire length of the north side and was used in earlier days as a ballroom. Two stoves, one in each end, heated the room that evidently once had two large chandeliers hanging from the ceiling.

Across the hall is a small room with hooks on the walls. This was used as a cloakroom for guests.

One small bedroom has only one entrance while another room that was probably used as a bedroom, has two entrances, one to go down the back stairs and one to go down the front stairs. Across from the latter bedroom is a very small attic-like room which probably was used by servants of the household and by people on the stage staying overnight.

The back stairs are steep and curve into the kitchen under the "servants' quarter." The front stairs are elegantly carved of dark walnut. A beautiful sheen is on the stairs from age, not varnish. Some of the balusters are missing because of kids removing them from the stair.

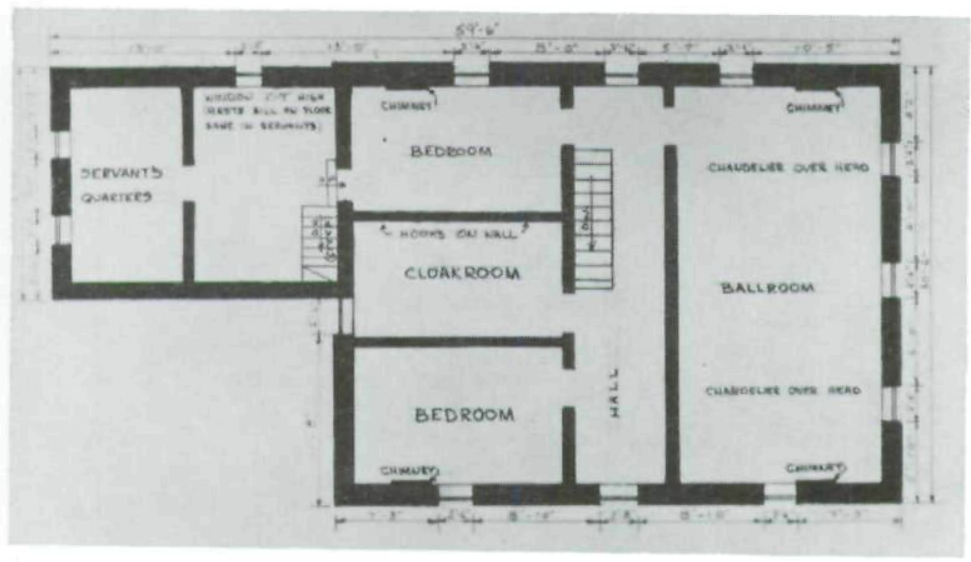

Second Floor Plan 
Downstairs, under the ballroom, are the two most richlooking rooms of the house. One room was used as a bar room. A hanging wall bar of dark walnut was used to store liquors. A counter-type bar was used to serve the guests. The impressions of both bars are still on the walls but the bars have since been removed and are in the home of a great-grandson of the builder. In the bar room, a dado of alternating oak and walnut vertical boards add much richness to the room. This dado appears only in this room.

The room next door may have served as a living room. This room and the bar room have dark mouldings around their doors and windows. The windows throughout the house have been set in one foot from the surface of the inside walls. In the living room and the bar room coffers are in the insets of the windows.

A dining room with parlor attached is located in the center of the house. The woodwork here, as everywhere in the house but in the living room and bar room, is light in color and the mouldings have a particular shape.

The kitchen may or may not have had an actual fireplace. There is a chimney in that section of the house but no fireplace now. An impression is on the south wall, but it may have been made by a cabinet.

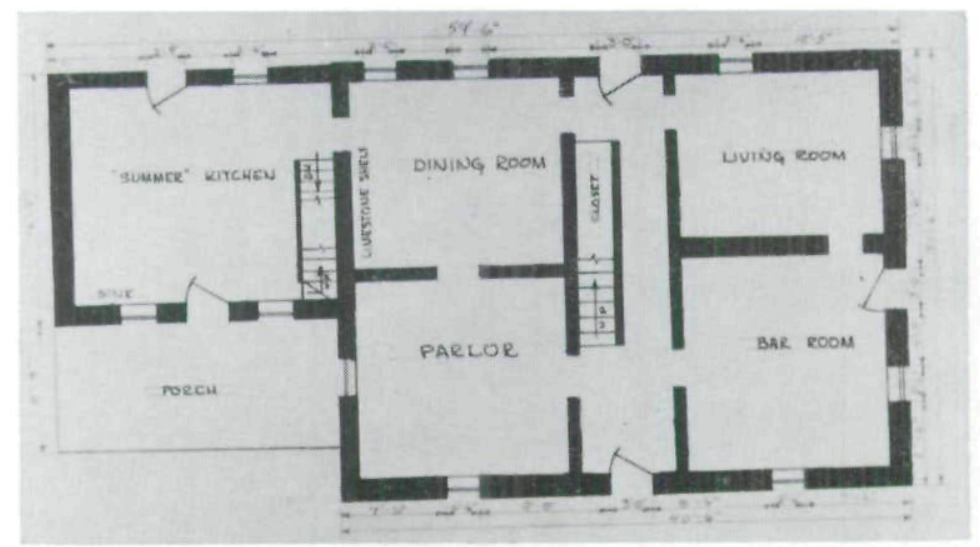

First Floor Plan 
There is a full basement which is approached from a steep stairway from the kitchen. A cellar door on the porch floor also opens into the basement.

One of the exterior features of the home is the number of chimneys-five in all-one on the one-half story kitchen which juts out to the rear of the house and one on each of the four corners of the two-story main section. For this reason, some of the local residents often refer to the home as the house of five chimneys.

Descendants of the Powers living in the area report that the number of chimneys on the house seems to stir up controversy from time to time-and at the oddest hours. They have received a number of early morning phone calls from persons wanting them to settle a bet on the number of chimneys on the house.

Although the area residents speak of the house as the Old Tara Stagecoach House, the house was probably built with the only purpose of being a home for the Powers family. It is not of the architectural style of the area which creates the speculation about it being built as a stage stop.

Because of the size of the house and its location on the Fort Dodge to Sioux City stage line, the home just happened to be used as a stagecoach stop. During the days when stagecoaches were operating in the area, teams were changed every 12 to 15 miles and the home is located midway between Fort Dodge and Twin Lakes, which is about 25 miles west of Fort Dodge. Twin Lakes was one of the towns served on the line.

The stagecoach line which used the Powers house as a stop, was probably the Northwestern Stage Company, operated by A. E. Haskell, one of Fort Dodge's early settlers. Haskell's line succeeded the Western Stage Company, one of the larger company's in the area before Haskell's line became the dominant firm.

Haskell operated the Northwestern Stage Company from 1863 until the 1870 's. Prior to that, the Western Stage Company was the dominant line from 1855 to 1863 .

Of the Powers' three sons, Stephen A., Tom and Walter, Walter was the only one who continued to live at home after the death of his father. The other two sons took portions of the 530 -acre tract and built their own homes. 
Walter Powers continued to live in the home until 1913, when he moved his family into Fort Dodge. When he died in 1923, the house and land were handed down to his son, Leon W. (Judge Powers of Denison), who sold the house and 190 acres with it, late in 1958 to Miss Margaret Banwell, RFD 3, Fort Dodge.

A family lived there for about 30 years after the Walter Powers family moved to Fort Dodge. After them, there were a number of other tenants until the middle of 1957. All in all, the house was occupied for 100 years.

The house is now in a state of disrepair-the bricks are crumbling, outside limestone door lintels and window bases are weathered and much of the plaster has fallen down inside -the house still retains some of the dignity and majesty that must have belonged to it years ago. Vandals have entered the house from time to time and torn out several balusters of the main stair.

The sale of the Powers home out of the family closed an era. Gone are the stagecoaches and gone are the teams of horses which raised a cloud of dust as they arrived in the summer and kicked up soft flurries of snow during the winter. The old house stands alone.

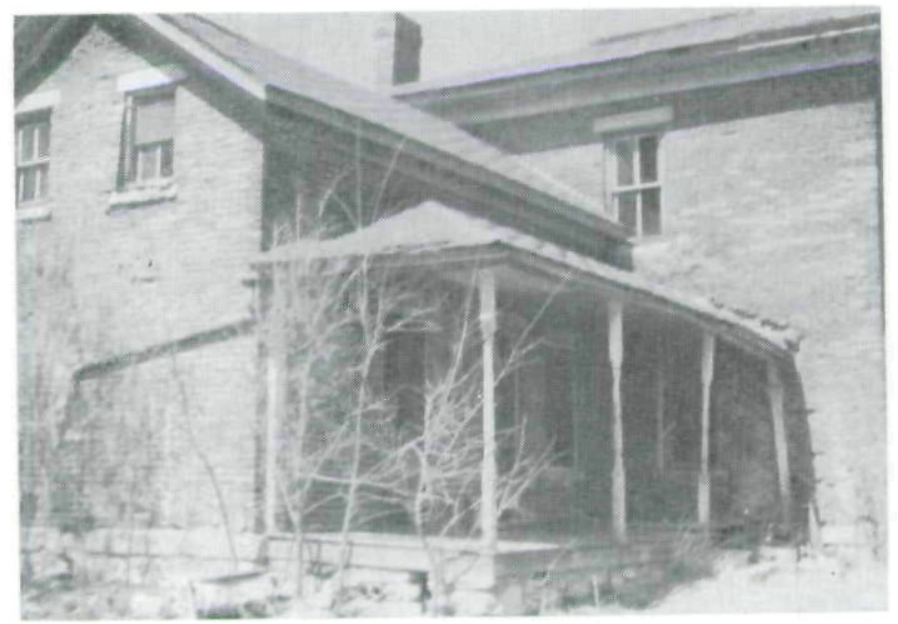

These selected studies of Iowa architectural history will be continued in the Spring issue of the Annals of Iowa. 
Copyright of Annals of Iowa is the property of State of Iowa, by \& through the State Historical Society of Iowa and its content may not be copied or emailed to multiple sites or posted to a listserv without the copyright holder's express written permission. However, users may print, download, or email articles for individual use. 